\title{
Perceptions of Customary Land Tenure Security in Western Province of Zambia
}

Niraj Jain ${ }^{1}$, Roy Chileshe ${ }^{1}$, Francis Muwowo ${ }^{1}$, Majory Lupiya ${ }^{1}$

${ }^{1}$ School of the Built Environment, the Copperbelt University, Kitwe, Zambia

Correspondence: Niraj Jain, School of the Built Environment, the Copperbelt University, P. O. Box 21692-Kitwe, Zambia.

Received: December 24, 2015

doi:10.11114/ijsss.v4i2.1264
Accepted: January 19, 2016

Available online: January 21, 2016

\begin{abstract}
This paper presents the empirical findings of a research study undertaken in the Western Province of Zambia. The principal objective was to explore if the issuance of land ownership certificates (LOCs) improves the customary landholders' perceptions of security of tenure. Thus, we test a null hypothesis that: 'There are no significant differences in the perceived security of tenure between customary landholders with land ownership certificates and customary landholders without land ownership certificates'. A survey was undertaken of customary landholders and land administration officials using structured in-depth interviews and group discussions. The research used a mix of qualitative and quantitative approaches where the views of customary landholders with certificates were compared with those with none based on a security of tenure assessment framework. It was revealed that the land ownership certificates (LOCs) provide the customary landholders with a perceived protection from losing land rights. However, the LOC does not improve other perceptions of customary landholders towards tenure security. In fact most of the perceptions of customary landholders with land ownership certificates are statistically not any different from the others. All customary landholders perceive their tenure as secured under the customary land administration in Western Province. The paper concludes by stating that the absence of a legal recognition renders the LOC insignificant in enhancing the perceived security of tenure. Legal recognition of the customary land administration system in Western Province of Zambia is therefore recommended.
\end{abstract}

Keywords: Perceived Security of Tenure, De jure Security of Tenure, De facto Security of Tenure, Customary landholder, Land Ownership Certificates (LOC)

\section{Introduction}

Numerous works have been commissioned to explore tenure security around the world but little has been done in Zambia particularly in the rural environment. Literature shows that there is hardly any disagreement on the strength of formal property rights in bestowing security of tenure. In fact, statutory tenure raises little concerns as it grants de jure security of tenure. Customary tenure on the other hand, tends to be a subject of discussion in many research works. Customary land rights are based on local customs and not formal or state title deeds as is the case with statutory tenure (Van Asperen \& Mulolwa, 2008). Consequently, there has been a growing concern from the international community to reform customary land by converting it to statutory tenure (Lamba, 2005). Such reforms, however, are said to be the very cause of tenure insecurity on customary land, for example, people fear that their customary land can be expropriated by government and allocated to private investors at any time (Chileshe, 2005). It therefore becomes essential to explore how the customary land tenure system can be strengthened in itself. In this context, the customary land tenure system in Western Province provides several unique lessons.

Quite unlike other chiefdoms in the Country, Western Province has a land administration system where Land Ownership Certificates (LOCs) are issued as a proof of customary land ownership (Roth et al, 1995). And this seems to be a growing trend in many other countries in the sub-Sahara Africa where countries like Tanzania, Botswana and Uganda issue customary title deeds to landholders (Sundet, 2005; Willy, 2003; and Kalabamu, 2000). A priori knowledge suggests that such traditional titles of ownership should provide a security of tenure since a title deed is perceived by many as the definite proof of ownership (Deininger, 2003).

This raises many fundamental questions as to whether such traditional titles of ownership in effect enhance the perceptions about security of tenure at the grassroots level. Empirical findings can be significant in that they can be used by policy makers to either roll out the issuance of customary titles of ownership to other Chiefdoms in the country; or develop empirical- based strategies on how such titles of ownership can be integrated into the formal statutory 
system.

Hence, using a survey approach, this research paper investigates if the perceptions of customary landholders in Western Province of Zambia with some proof of landownership are any different from those with none. The paper commences by presenting background literature on security of tenure, customary land tenure and the land administration system in Western Province of Zambia. In subsequent sections, the methodology, results and discussions and conclusions are elaborated.

\section{Background}

\subsection{Perceived Security of Tenure}

Security of tenure has been defined in many ways by scholars, viz.: Mitchell (2011) describes security of tenure as the degree at which there is certainty of people, the state or other entities recognizing the land rights that belong to others and that there is a level of protection in the event that a landholder's rights are threatened. It is conjectured that security of tenure provides: lower transaction costs (Feder, 1987; Hollingsworth, 2014; and Deininger et.al., 2006); social stability through lesser conflicts and disputes (DFID, 2007; and Deininger et.al., 2006); higher agricultural productivity (Feder, 1987; Adams, 2004 and Smith, 2004); sustainable development (Holden, 2006; Quan et al., 2004); and fiscal planning and revenue generation (UN-Habitat, 2008).

Deininger and Feder (2009) claim that the positive effect of security of tenure on investment has been evidenced in China, Thailand, Latin America, some parts of Africa and Eastern Europe. Paradoxically, some studies reveal that investments in land may not be as a direct result of security of tenure. Payne and Quan (2008) and Deininger (et al, 2006) assert that de jure security of tenure provides a collateral for accessing credit for developing land. But there are arguments that even though people have title deeds they are unable to access credit because they are either reluctant or just not willing. Critics have failed to find empirical evidence to show how title can possibly provide an avenue for accessing credit easily and at a cheaper cost (Brasselle et al, 2002). Besides, Hollingsworth (2014) identifies many other requirements as pre-conditions for credit worthiness such that security of tenure ought to be understood differently.

According to the UN-Habitat (2008), security of tenure is "a feeling of safety in holding a piece of land." Broegaard (2013) reinforces this understanding by stating that security of tenure is about being safe in the expectation of reaping the rewards of one's investments. This definition contends that security of tenure ought to be about the perceptions landholders hold with respect to their land.

Traditionally, the highest form of security of tenure is believed to arise from de jure rights granted by the State (see for example Lanjouw \& Levy, 2002; Deininger, 2003). However, Usamah et al (2012) contend that de jure security of tenure might be legally legitimate but may not necessarily be socially legitimate.

On the other hand, de facto security of tenure is said to be socially legitimate but may often exist without legal recognition of land rights (Payne, 2001). It has to do with a mutual understanding between the landholders and the community and/ or social relations. Scholars in fact add that the mere recognition by the community and social relations confer more security to landholders as opposed to recognition by statutory bodies. This implies that de facto security of tenure may actually be more important than de jure security of tenure. This assertion is supported by Hollingsworth (2014) and Lanjouw \& Levy (2002).

Hollingsworth (2014) and Van Gelder (2010) in fact suggest that security of tenure is more of a psychological variable that consists of both the states of thinking and feeling. Doebele (1978: 111), states that even though tenure is considered as legal it is just a matter of the 'state of mind' of the landholders. Therefore, security of tenure is what the landholders perceive it to be. Payne (2001: 421) provides that, "it is undeniable that perceived security of tenure is widely accepted as a precondition for households to invest in house construction or improvements. This is not the same thing, however, as saying that full titles are the only means of achieving acceptable levels of security." Payne and Durrand- Lasserve (2012) also add that perceived security of tenure is more important than its legal recognition. Usamah et al (2012) add that landholders are capable of investing their capital in construction and expansion of houses as a result of confidence arising from the perceived security of tenure that they have.

2.2 Customary Land and Security of Tenure

Customary tenure refers to the holding of land based on customs/traditions (Van Asperen \& Mulolwa, 2008). Land ownership of this category relates to the communal possession of land rights. In most cases a single person in the group administers this on behalf of the entire group (Payne \& Durand-Lasserve, 2012). And the role of Chiefs on customary land is to act as a regulator of acquisition and use of land (Van Loenen, 1999).

This type of tenure is found in most African countries and land held under such conditions is regarded as sacred. As such, the role of landholders is to protect the land for the interests of the past, present and future generations. Land rights that can be held as: individual rights, communal rights and concurrent interests (Chileshe, 2005). Although 
permanent, theses rights may end by transfer, abandonment, death or expulsion from the community.

The customary land tenure system is therefore regarded as being insecure. The tenure insecurity results from the lack of legal title deeds (Deininger, 2003). The absence of de jure security attributes to the lack of protection of land rights by the state. Thus, when other people make claims on their land, land holders fear that their land rights will be expropriated (Lamba, 2005). In fact, Chiefs tend to abuse their positions to accumulate wealth by depriving the indigenous people of their land rights and extracting monetary benefits from strangers (Akrofi and Whittal, 2011). This also contributes to the tenure insecurity that customary landholders face. Besides, poor governance practices (Akrofi and Whittal, 2011) and corruption (UN-Habitat, 2014) are all equally said to be an impediment in the security of tenure.

Nevertheless, most customary landholders are said to enjoy de facto security of tenure or perceived security of tenure (Hollingsworth, 2014) and are content by the mere plantation of trees on their lands to indicate that the plot is already occupied (Van Asperen and Mulolwa, 2008).

Customary land tenure in some neighbouring countries like Botswana and Tanzania draws its strength from dedicated legislative instruments that provide for the establishment of customary tenure- its allocation process and; more importantly the issuance of certificates of title. Take for instance, the Tribal Lands Act of Botswana provides for the establishment of land boards and gives them all the land related powers that once belonged to Chiefs (Bornegrim \& Collin, 2010). The Act lays out procedures to be followed when granting certificates of customary land (Republic of Botswana, 2010). White (2009: 1) states that the Tribal Lands Act vests, "all the rights and title to land in each tribal area ... in the land board ... in trust for the benefit and advantage of the tribesmen of that area and for the purpose of promoting the economic and social development of all the peoples of Botswana." According to Kalabamu (2000) the land administration system in Botswana has prevented Chiefs from abusing their authority and allocating big portions of land to themselves or selling land on their own.

The Village Lands Act of Tanzania is not very dissimilar. It decentralizes the administration of village land to the village (Sundet, 2005). This means that the Act empowers the villages to manage and administer their own lands. The Village Lands Act statutorily recognizes customary land rights.

Not so distant, the Ugandan customary land tenure equally draws its efficacy from the Lands Act of 1998. It decentralizes the management and administration of customary land in Uganda (Willy, 2003). One of the functions of the land boards created under this Act is to oversee the land rights held by landholders in Uganda (Rugadya, 1999). Additionally, customary tenure is fully recognized as equal in legality with the other three formal land tenures in Uganda (Willy, 2003). Certificates of customary ownership are issued by district land boards (Willy, 2003). This certificate is the definite proof/evidence of ownership.

Evidently, these nations provide a de jure security of tenure quite unlike the practices in Zambia. Land in most customary areas of Zambia is still managed and administered by Chiefs who do not grant any form of evidence to show landownership. Rampant cases of evictions and displacements within the customary lands are a clear testimony (Van Asperen \& Mulolwa, 2008) e.g., in Mpongwe (Copperbelt Province), farmers were evicted from 46, 876 hectares of customary land by a South African based agribusiness (Mulenga, 2014).

Furthermore, external factors also contribute to the insecurity of tenure. These external factors, according to Chileshe (2005) include: availability of an alternative tenure, introduction of the money economy and increase in population pressures. It is reported that when outsiders were allocated customary land, they applied for statutory title deeds (through conversion) (Chileshe, 2005). The absence of proof of ownership therefore makes people insecure.

\subsection{Customary Land Administration in Western Province of Zambia}

Prior to the commencement of the British colonial rule in 1880s, all land in Zambia was administered and managed by indigenous institutions through the use of customary laws (Adams, 2003). Around the 1890s, agents of the British South African (BSA) Company went to Lewanika (the Lozi King) in Barotseland (now Western Province) with the intention of securing concessions over land (Roth et al, 1995). Resulting from this was the authority of the BSA Company to have control over land in Zambia. Nevertheless, the BSA Company was not allowed to control land in the whole of Western Province (Metcalfe \& Kepe, 2008). This meant that the Litunga still maintained power over land. Hence, when the Northern Rhodesia (Crown Lands and Native Reserves) Order in Council of 1928 was passed, the Barotseland was not affected by the then newly created Crown Land and Reserves (M'membe, 2005; Sichone, 2008). The unique and separate existence of Barotseland continued to exist as such through the orders made between Lewanika and the BSA Company. On $18^{\text {th }}$ May 1964, the Barotseland Agreement was passed. This Agreement was made by the Government of Northern Rhodesia (now Zambia) and the Litunga of Barotseland (GRZ, 1967). The Agreement enabled the Litunga to continue enjoying the greatest measure of responsibility for land administration in Barotseland (Adams, 2003).

Post-independence, reforms were made to the land tenure system. Land in Zambia could only be held (and is still only held) either under customary tenure or statutory tenure (Sichone, 2008). However, the Litunga's control over land in Western Province persisted until the enactment of the Western Province (Land and Miscellaneous Provisions) Act of 1970 (M'membe, 2005). 
Although, Chiefs are the institutional bodies of land administration as recognized by the Constitution of Zambia (Van Asperen and Mulolwa, 2008), the Lands Act (No 5 of 1995 of the Laws of Zambia) does not recognize Chiefs as owners of land. All 73 tribes in Zambia administer land based on their unique customs and traditions (Mulolwa, 2006). Differences in traditions are seldom insignificant (Chileshe, 2005) because many exhibit similarities in their land administration systems. In most cases, Chiefs are dependent on village headmen for assistance in the land administration system. Customary land is generally not directly allocated by Chiefs. Instead, Chiefs allocate land to sub Chiefs who in turn allocate land to village headmen who are responsible for the allocation of land to villagers (Nsemiwe, 2007).

\section{Methodology}

This paper presents the findings of an empirical research study designed to investigate whether the land ownership certificates issued in the Western Province of Zambia enhance customary landholder's perception about security of tenure. In doing so, the researchers also sought to document the land administration process in the Province.

An assessment framework was designed based on the works of UN- Habitat (2011), Hollingsworth (2014) and Kiddle (2011). Hollingsworth (2014) identifies a number of key proxies for measuring security of tenure from academic literature and monitoring initiatives of UN agencies and several other organisations. Perception of security is however, not adequately captured by Hollingsworth (2014). Kiddle (2011) raises some intriguing questions about perceived security of tenure that are integrated into the Hollingsworth (2014) framework. The consolidated framework therefore focuses on a number of relevant indicators for establishing the perceived security of tenure as shown in Table 1 .

Table 1. Indicators of Perceived Security of Land Tenure

\begin{tabular}{rll}
\hline Ref & Relevant Indicator & Details \\
\hline 1. & Perceptions of future loss & Risk of losing a land right \\
2. & Recognition of land rights held & $\begin{array}{l}\text { Recognition by State, Traditional Land Administration Authority } \\
\text { and local community }\end{array}$
\end{tabular}

3. Availability of title

Ease of issuance; its essence and role in security

4. Loss of rights in the past

Actual instances of loss of land rights

5. Threat of evictions

Protection from Traditional Authority

6. Bundle of rights held

Autonomy in right to sale and; exclusivity in enjoyment

7. Access to credit

Actual instances or perceived

Description: A framework for measuring perceptions about security of land tenure Source: Adapted from Hollingsworth (2014)

The study was generally qualitative in nature, although quantitative tools (particularly, the Fisher's Exact Test) were used to test the following hypothesis:

Null Hypothesis $\left(\mathrm{H}_{\mathrm{o}}\right)$ : There are no significant differences in the perceived security of tenure between customary landholders with land ownership certificates and customary landholders without land ownership certificates; and Alternative Hypothesis $\left(\mathrm{H}_{1}\right)$ : There are significant differences in the perceived security of tenure between customary landholders with land ownership certificates and customary landholders without land ownership certificates.

With the help of the Barotse Royal Establishment (BRE), the researchers identified a traditional settlement with the highest concentration of customary landholders with LOCs- the Malengwa settlement in Mongu. Limulunga area, which forms the capital of the customary areas (and houses the main Kuta- the Lozi traditional court as well as the Litunga) was also incorporated in the study. However, due to poor record keeping, the actual number of customary landholders could not be established. Hence, after extensive consultations and negotiations with the BRE, the sampling size of customary landholders had to be restricted to fifteen interviewees in each of the two strata (those with LOCs and those without LOCs). In the wake of the controversies surrounding the 1964 Barotseland Agreement, land related matters are very sensitive in Western Province such that a larger sample size was not possible.

Nonetheless, since data saturation occurs by the $12^{\text {th }}$ interview of a homogenous group (with a Cronbach's alpha of 0.7 ) (Guest, et.al., 2006 cited in Saunders, et.al., 2009), 30 interviewees (15 in each of the two strata of customary landholders) were considered adequate for this study. Further, two members of staff were identified from each of the 
statutory institutions; and three members from the BRE (Table 2).

Table 2. Sampling Frame

\begin{tabular}{|c|c|c|}
\hline $\begin{array}{l}\text { CATEGORY } \\
\text { (sampling units) }\end{array}$ & $\begin{array}{l}\text { INTERVIEWEE } \\
\text { (units of inquiry) }\end{array}$ & $\begin{array}{r}\text { NUMBER OF } \\
\text { INTERVIEWEES }\end{array}$ \\
\hline $\begin{array}{l}\text { Custodians of customary } \\
\text { land }\end{array}$ & Barotse Royal Establishment (BRE) members & 3 \\
\hline \multirow[t]{3}{*}{ Statutory institutions } & Mongu Municipal Council Officers & 2 \\
\hline & $\begin{array}{l}\text { Ministry of Lands } \\
\text { (Lands Department in Mongu) Officers }\end{array}$ & 2 \\
\hline & Department of Agriculture in Mongu Officers & 2 \\
\hline \multirow{2}{*}{$\begin{array}{l}\text { Landholders } \\
\text { chiefdom }\end{array}$} & Customary Landholders with LOCs & 15 \\
\hline & Customary Landholders without LOCs & 15 \\
\hline
\end{tabular}

Description: Categories of interviewees identified for the research study Source: Authors, Field Survey 2014

In identifying the actual interviewees from the two strata of customary landholders, the BRE, the Mongu Municipal Council, Ministry of Lands and the Department of Agriculture, the snowballing approach was used.

Interview guides were designed for all sample members while group discussions were focused on the BRE members.

A reconnaissance visit was undertaken in order to develop a rapport in the Province. In fact, most traditional leaders do not entertain surprise visits. Many consider it to be disrespectful. As a result, a senior chief (known as Induna Inete) who is also a member of the Lozi traditional court ' $K u t a$ ' and the Barotse Royal Establishment (BRE) played a pivotal role in establishing the contacts for this study. The fieldwork was settled for one week in the month of November 2014. Qualitative data was analyzed using the narrative approach where themes were created from the interviewees' answers. This approach allowed us to preserve the integrity and, convey actual social understandings of perceptions held by customary landholders. Furthermore, audio/ video-recordings of interviews were made to thoroughly capture the field data.

\section{Case Study Profile- Mongu}

Western Province comprises of 7 districts namely: Lukulu, Kaoma, Kalabo, Senaga, Sesheke, Mongu and Shang'ombo. The provincial capital: Mongu that was selected as the study area of the research is bordered by Senaga, Kalabo, Kaoma and Lukulu (See Figure 1).

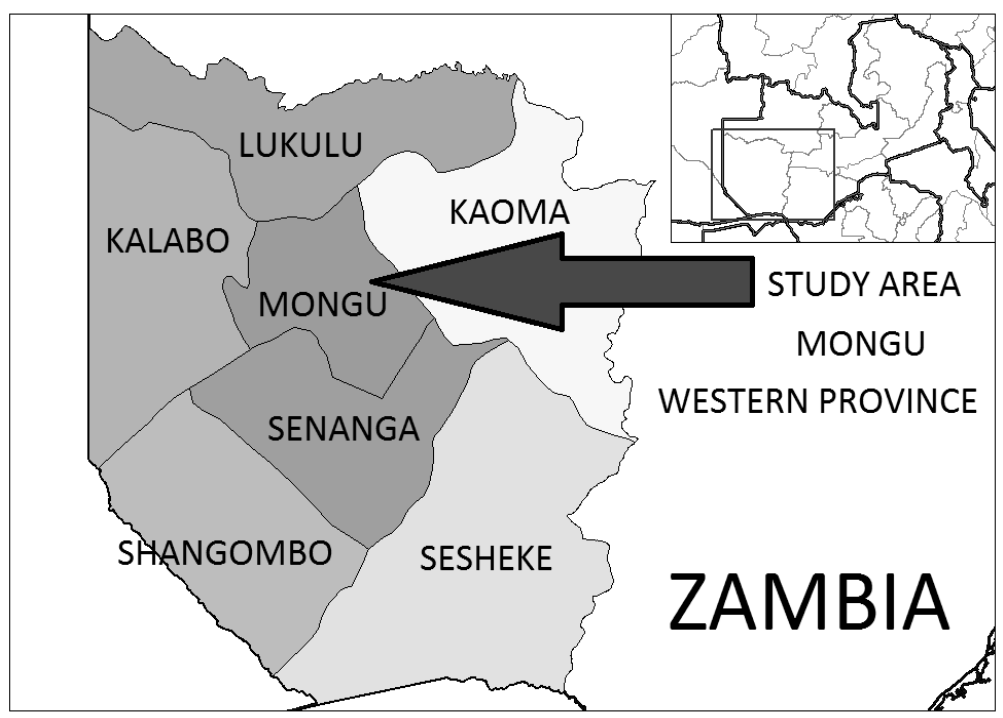

Figure 1. Locational Map- Western Province (Adapted from Wikipedia, 2015)

Mongu district of the Western Province was selected because it has a well- organized customary land administration 
system and forms the administrative hub for the Litunga.

\section{Results and Discussion}

5.1 Litunga and the Barotse Royal Establishment (BRE)

The Litunga is the overall head of the customary land administration system in Western Province. In fact he is referred to as 'Minya-Mupu-Na-Ngombe' (the owner of land and cattle). As a member of the BRE and the Kuta, the Litunga is privy and final authority to all land related matters. In Lozi, it is stated: "FoKutabile ngweshi" meaning that, "where the King has pierced no man can remove.” (BRE Group discussions, November 2014)

The above statement signifies that if the Litunga makes a decision no one can oppose or refute it. Customary land in Western province is administered by BRE which consists of many members starting (in hierarchy) with the Litunga (at the top), Senior Chiefs (Induna Inete), Sub-Chiefs also known as area chief (Induna wa Silalo) and ordinary Indunas (Induna wa Silalanda). Other members of the BRE include the "Ngambela" and the "Natamoyo".

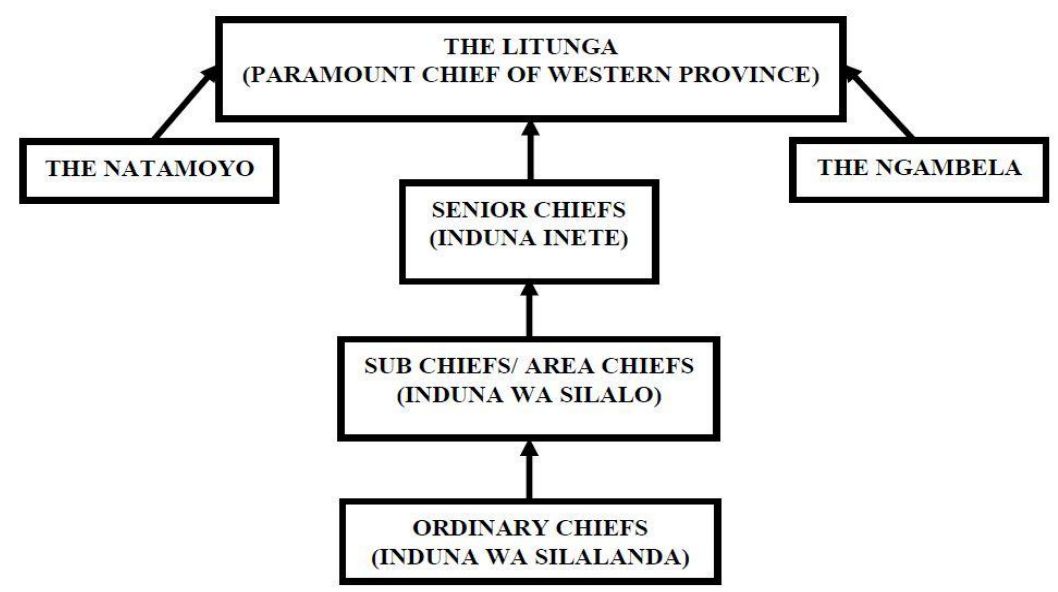

Figure 2. The Barotse Royal Establishment (BRE)

Description: Composition of the Barotse Royal Establishment (BRE) showing various categories of Chiefs and Royal family members being headed by the Litunga(Source: Authors, Field Survey, 2014).

The "Ngambela" is the prime minister. He is the Litunga's spokesperson. This is because the Litunga does not communicate directly with his subjects. It is the "Ngambela's" responsibility to act as the medium of communication between the Litunga and his subjects. Another role the "Ngambela" plays is to stand for commoners in the day to day activities of the community.

The role of the "Natamoyo" is that of a Minister of Justice. S/he pleads on behalf of the individuals in the community. The "Natamoyo" is a member of the royal family and is also called the "the mother of life/saviour." Every district in Western Province is headed by a senior chief. He is also referred to as an "Induna Inete".

Like the land boards (in Uganda and Botswana) and Village land councils (Tanzania), Western Province has counts ("Silalo") and sub-counts ("Silalanda") which have similar roles and responsibilities at differing levels of authorityresolving disputes, allocating land and implementing customary laws.

The "Silalanda" is headed by ordinary Indunas (Induna wa Silalanda) and is subordinate to the "Silalo". Whereas, the Silalo is headed by area/sub-chiefs (Induna wa Silalo) and is made up of Silalandas. The Silalanda comprises of 12 villages.

\subsection{Traditional Land Ownership forms}

According to the Mongu Municipal Council all land in the district (about $10,720 \mathrm{~km}^{2}$ ) is held by the Litunga. A mere $30 \mathrm{~km}^{2}$ is regulated under the statutory tenure. It was also found that there are five traditional forms of landownership.

The Mubu-Wa-Ngweshi, which refers to all land that belongs to the Litunga. It is passed on from one Litunga to the other. This is the parcel of land from which the Litunga allocates land to people who request/ apply for land acquisition. Such land may be allocated for purposes of settling, agricultural or development.

The Mubu-Wa-Luu land is given to individuals who are said to be the custodians of customary land. These include the senior chiefs, sub- chiefs and members of the Royal family. Acquisition of this land is attached to the position an individual holds in the BRE. 
Mubu-Wa-Bana-ba-Malena is held in trust by members of the Royal family. It is passed on from one generation to the other. However in cases where there is no one to inherit the land, it escheats to the Litunga. Management of this land is undertaken by the Royal family with the help of the Indunas.

The fourth form, the Mubu-Wa-Lusika is 'owned' by the subjects. It is passes from one generation to the next.

And the final form called the Mulalambuwa does not belong to any one and no one inhabits it. An individual interested in acquiring this land must follow prescribed procedures through the Silalo Indunas.

\subsection{Land Allocation and Dispute Resolution}

Some interviewees claimed that there is a set of written rules used by the BRE in customary land administration. However, these were never made available to the authors. Nevertheless, since the state does not provide any legal basis for customary tenure, such rules (if existing) will be ineffective in providing de jure security of tenure.

In any case, land allocation in Western Province begins from the household level (Lozi family members). Every indigenous person (i.e., Lozi person) in Western Province is entitled to a parcel of traditional land whether female or male. The family members acquire land through inheritance or as gift. However, if a family runs out of land, they may approach the village headman known as "Sibuku" in Lozi. The village headman allocates land if available. Notwithstanding the status quo, if the village headman has no land available, the applicant is referred to the "Silalanda" and thereafter progressively to the "Silalo". The latter comes in when the "Silalanda" is unable to allocate land from within the 12 villages.

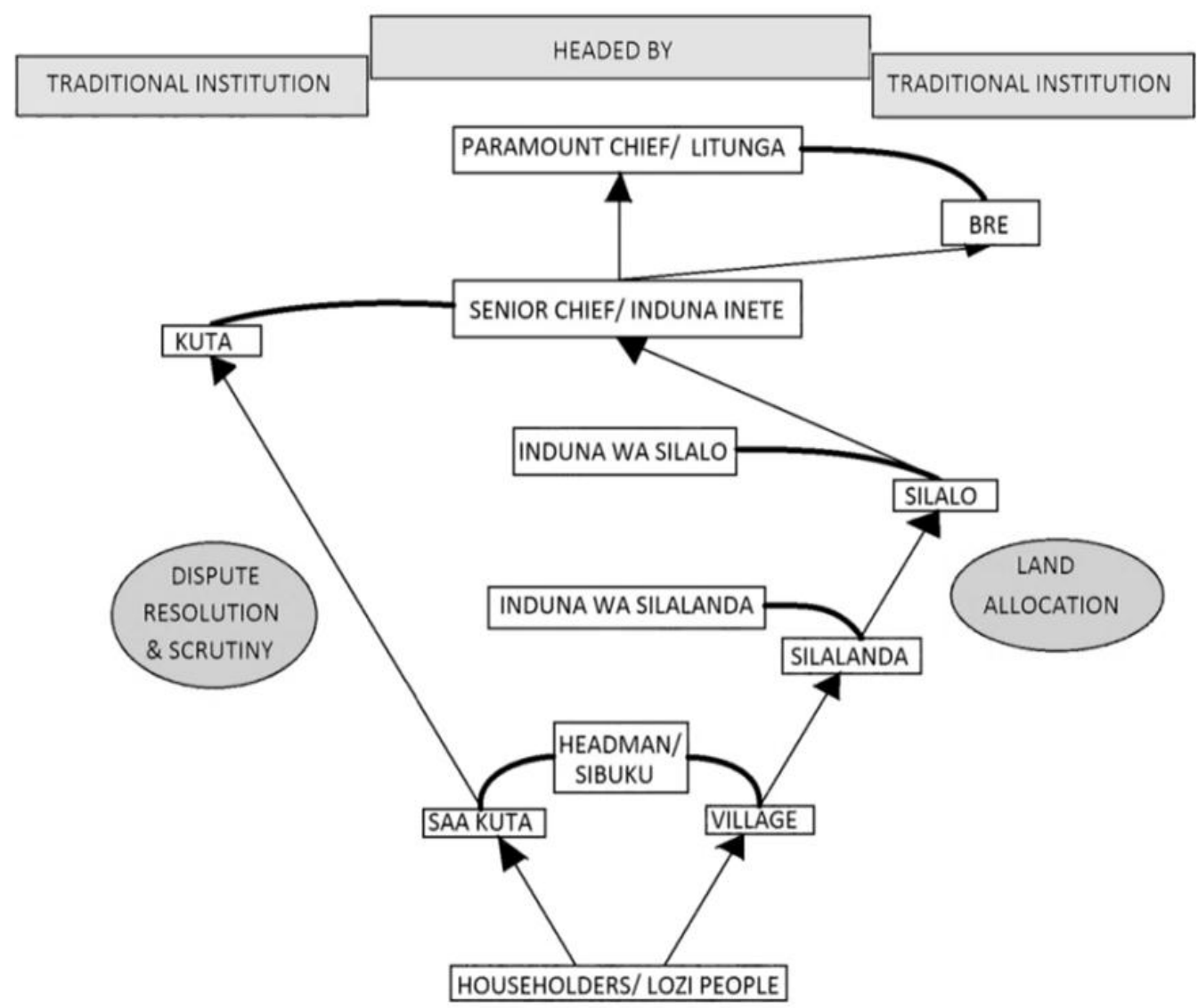

Figure 3. Customary Land Administration process in Western Province

Description: Customary land administration process in Western Province showing the two streams: land allocation and dispute/conflict resolution. The process commences from the householders' level and then gradually ends at the level of the paramount Chief (Source: Authors, Field Survey 2014).

In addition to the above bodies, the area/sub-chiefs are also responsible for land allocation when the "Silalo" is unable to do so. Next in the hierarchy is the Senior Chief- the "Induna Inete".

At the apex is the Litunga, who is the overall authority from whom any person can acquire land if all other subordinate channels have proved to be futile. This effectively means that land is allocated at all levels based on availability. However, the LOC is only granted by the BRE. 


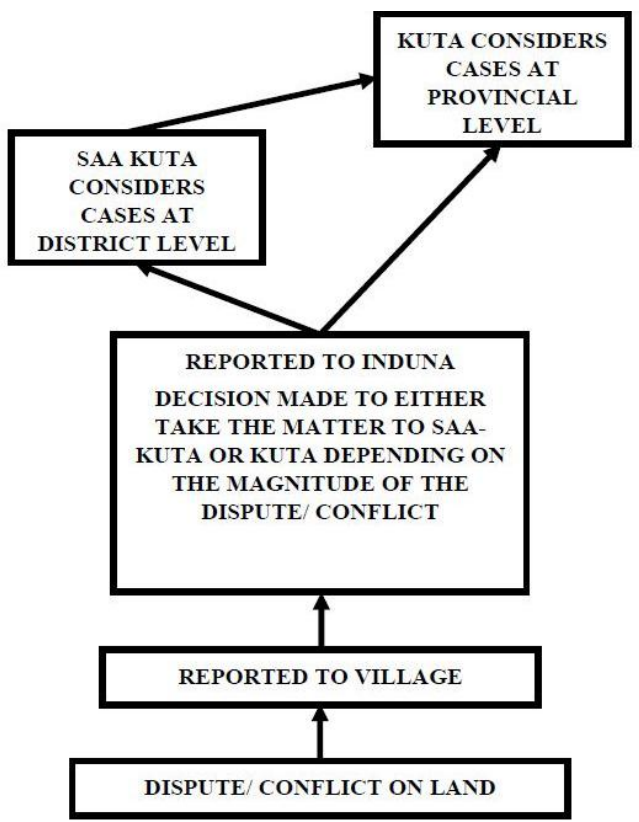

Figure 4. Dispute/ Conflict Resolution process in Western Province

Description: Dispute/Conflict resolution process in Western Province. It is shown that the Indunas play a pivotal role in land conflict resolutions(Source: Authors, Field Survey 2014).

Like the lands tribunal in Botswana, the "Kuta" is responsible for handling conflicts amongst customary landholders. However, its functions are not only restricted to land disputes, the group discussions also revealed that the "Kuta" is responsible for scrutinizing people who apply for land. The head of the "Kuta" is the Senior Chief and in most cases handles matters of conflict at the provincial level. However, he does not unilaterally take decisions but involves other Indunas in the area. There is a "Saa-Kuta" which is a Lozi traditional court at the district level. Customary landholders in Western Province appeal to the "Kuta" for dispute resolution only where the headman fails to satisfactorily adjudicate in the Saa-Kuta.

Members of the "Kuta" include the Litunga though he only attends selective meetings, the senior chiefs, area/sub-chiefs and ordinary Indunas. It was found that the main "Kuta" is located near the Litunga's residence in Limulunga (Mongu, Western Province).

\subsection{The Land Ownership Certificates (LOCs)}

Based on the group discussions held with the BRE, it was found that long before the introduction of LOCs in the Western Province, customary land allocation was similar to other customary areas in Zambia where customary land is allocated by "mere word of mouth" (see also Sichone, 2010). Back then, a person interested in land would approach the village headman for assistance in acquiring land. The village headman would in turn go to the superior bodies of land administration for example the Silalanda to request for land on behalf of the interested party. In this case, the "Kuta" which is a Lozi traditional court would then hold a meeting to discuss availability of land for allocation. In addition, the "Kuta" would also establish the trust worthiness of the applicant. Successful applicants were required to pay homage known as "Showelela". Showelela refers to a loyal salutation to the Litunga as a sign of receiving land and showing appreciation for being granted that parcel of land (Group Discussions with BRE members, November 2014). Failure to observe Showelela is considered disrespectful as it shows ingratitude. This Lozi custom is a must. The group discussions with the BRE in fact revealed that this act which signifies payment of homage signalled that the land now belonged to the applicant- effectively sealing the transaction. After this, the Litunga would by 'word of mouth' state that the land belonged to the applicant. It is at this stage that an applicant could voluntarily acquire a LOC from the BRE on the recommendation of a village headman or Induna.

The village headman or Induna is required to apply to the "Kuta" on behalf of the applicant. Following this the Induna or village headman physically takes the applicant to the "Kuta" for introduction and scrutiny. The group discussion also indicated that scrutiny is important to avoid double allocation of land. If the Induna's report is in affirmative, the applicant is granted a LOC. Thus, the LOC is prepared by the BRE in consultation with the Kuta. Where the LOC is being sought for an old allocation, the applicant is required to Showelela again. The issuance of LOCs is solely to provide a proof of landownership. However, the BRE sample members acquiesced that LOCs were also necessary to reduce cases of land contestations. 


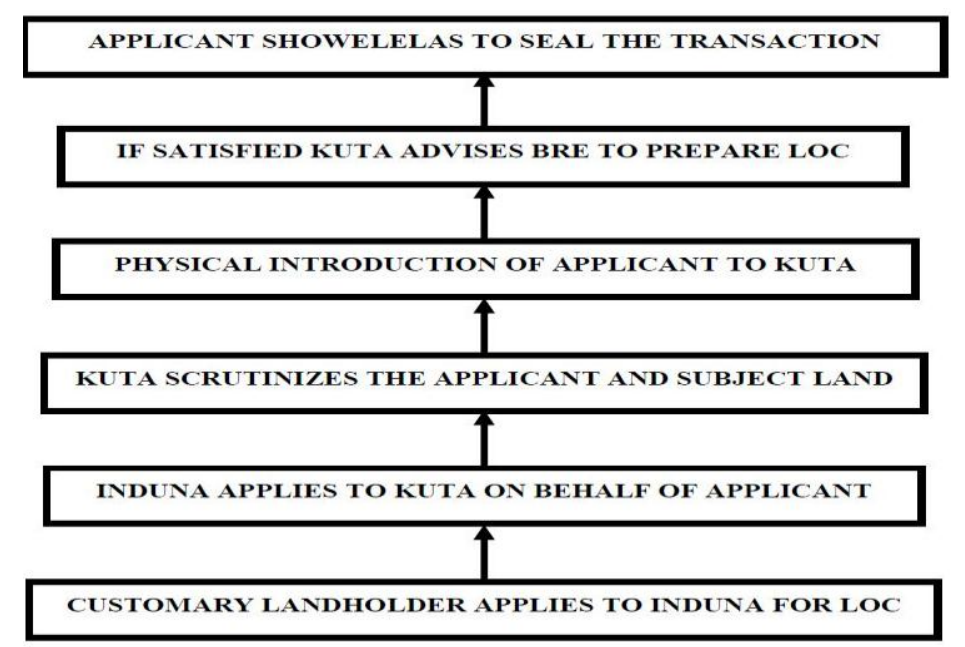

Figure 5. Land Ownership Certificate (LOC) Application Process

Description: Application Process for LOC. Note the 'Kuta' plays a pivotal role in soliciting a LOC for the customary landholder(Source: Authors, Field Survey 2014).

5.5 Characteristics of LOCs

The group discussions with the BRE showed that the LOCs ought to include (as shown in Appendix A):

1) The elephant

This is used as a symbol of traditional authority in the whole of Western Province and, any document showing this symbol is considered binding within the Lozi tribe;

2) The location of the land and, details of the customary landholder

The specific location of the land is geo- referenced with physical features/land marks in an area where the land lies.

3) A date stamp from the BRE

The LOCs must always be endorsed by at least four (4) Indunas for it to be binding. Where land was originally granted by the village headman, he must also endorse on the LOC.

It was further found that temporal LOCs are also issued in rare instances where the land allocation process was incomplete.

5.6 Basic socio- economic data of landowners

The findings show that most of the customary landholders were married (66.7\%); were between ages of 35 and 50 years (50\%); and studied up-to primary level (53.3\%).

Table 3. Socio- economic Data

\begin{tabular}{lcr}
\hline & Number & Percentage \\
\hline Marital Status: & 6 & $20 \%$ \\
Single & 20 & $66.7 \%$ \\
Married & 2 & $6.7 \%$ \\
Divorced & 2 & $6.7 \%$ \\
Widow/Widower & & $0.7 \%$ \\
& & $33.3 \%$ \\
Age Distribution: & 0 & $50 \%$ \\
Below 20 & 10 & $16.7 \%$ \\
$20-35$ & 15 & \\
$35-50$ & 5 & $16.7 \%$ \\
50 and above & & $53.3 \%$ \\
& & $16.7 \%$ \\
Education Level: & 5 & $13.3 \%$ \\
None & 16 & $100 \%$ \\
Primary & 5 & 4 \\
Secondary & 4 & \\
Tertiary & 30 & \\
Totals & & \\
\hline
\end{tabular}

Description: Basic socio- economic data of the 30 customary landholders(Source: Authors, Field Survey 2014) 


\subsection{Customary Landholders' Perceptions on Security of Tenure}

\subsubsection{Perceptions over future loss of land rights}

In Mongu, $66.7 \%$ (10) customary landholders with LOCs felt secure while very few without LOCs held a similar perception $(33.3 \%$ only). When customary landholders without LOCs were asked to give reasons why they felt insecure they attributed it to the fact that Indunas in the area easily change their decisions. They stated that:

"Indunas might allocate a parcel of land to an individual but later on give it to another. It is thus important to have a document that can prove landownership." (Personal communication with customary landholders, 2014)

This statement indicates that even though the Kuta scrutinizes availability of land, lack of precisely locating land parcels can devastate the land administration process. The survey also revealed that, already allocated plots are sometimes sub-divided for onward allocation to other people. Hence, customary landholders without LOCs feel insecure.

Moreover, no customary landholder with LOC claimed to feel insecure. In fact, the BRE members confirmed that in times of land contestations, customary landholders with LOC were favourably considered.

5.7.2 Perceptions on the recognition of customary land rights by the local community, the Customary land administration system and the State

Security of tenure is enhanced when the land rights of customary landholders are recognized by others- statutory bodies, customary bodies or people in the community generally. The recognition can either be legal or socially legitimate. From the works of the UN-Habitat (2011), this recognition gives landholders a confidence over land.

The findings reveal that $100 \%$ (15) of customary landholders with LOCs feel that their land rights are recognized by the local community since they hold a BRE endorsed land ownership certificate. As for the customary landholders without LOCs, 60\% (09) stated that they feel their rights to land are recognized by members of the community while the other $40 \%$ (06) claimed that their land rights are only partly recognized. The plausible explanation provided for the latter finding is that these specific individuals were settlers and not indigenous people of Western Province.

The significance of these findings is that there exists a social cohesion in the local community that grants a perceived security of tenure whether de facto or otherwise.

It was also found that all customary landholders (30) unanimously agreed that their land rights were fully recognized by the customary land administration system. However, their land rights are not statutorily recognized (de jure).

5.7.3 Perceptions on the essence of LOCs in land security

It was found that $66.7 \%$ (10) of customary landholders with LOCs and $93.3 \%$ (14) of customary landholders without LOCs think LOCs or any form of proof of landownership are necessary to feel secure. In fact, $73.3 \%$ (11) of the customary landholders with LOCs perceive to be better protected than their counterparts. 86.7\% (13) of customary landholders without LOCs stated that:

'...yes LOCs are a necessity especially in customary areas where there are no written laws that customary institutions should abide by as is the case on statutory tenure.' (Personal communication with customary landholder)

Furthermore, only $6.7 \%$ (1) of customary landholders with LOCs think that LOCs are not really that important for customary land. It was felt that after all the LOCs are not recognized beyond the traditional boundaries of Western Province.

5.7.4 Perceptions over losing land rights

The findings were that $66.7 \%$ (10) of customary landholders with LOCs think they are protected from losing their land whereas only $13.3 \%$ (02) of customary landholders without LOCs think they have protection. Moreover, customary landholders with LOC also said that: '[they] ...can use their documents to prove their rights to land therefore there is no need for them to feel threatened' (Personal communication with customary landholder).

The customary landholders without LOCs who claimed to feel protected stated that no one can attempt to take their land because people in the community know who has which parcels of land- social legitimacy (Usamah et.al., 2012).

The confidence that customary landholders have over their land can also be observed from the investments made to land. Most structures/houses on customary land were of a permanent nature using a combination of bricks and bamboos; or even blocks. Others were just built using local materials.

5.7.5 Perceptions on the administrative capacity in protection against evictions/ displacements

Based on the argument that landholders are secure if they believe that authorities have the capacity to protect them against evictions and/or displacements (UN-Habitat (2011), the study found: 86.7\% (13) of the customary landholders with LOCs believe that they are protected against evictions whereas only $46.7 \%$ (07) of customary landholders without LOCs feel protection will be provided to them if they face a threat of evictions/displacements.

5.7.6 Perceptions of the Bundle of legal rights held (rights to sell and exclusive use)

All customary landholders stated that they are not allowed to sell their land irrespective of whether they hold a LOC or not. And being a sacred free gift from God, no monetary value could be assigned to land. Further, evidence from the 
field survey showed that both strata of customary landholders have the right to deny others from using their land unless prior permission was sought. Apparently, the LOC played no role in generating a favourable perception on the right to exclusive use.

5.7.7 LOC and its perceived role in the access to credit

The research also tried to establish whether customary land in Western Province was used as collateral for accessing any form of credit- formal or informal. Of all the customary landholders, no one had attempted to access credit using their parcel of land as collateral. Traditional land was confirmed to be sacred that could not be sold. And using it as collateral was believed to be selling it. Ng'ombe and Mushinge (2014) in fact add that rights under customary land can only be transferred through bequest.

5.7.8 Statistical Significance in the differences in the perceptions of customary landholders with/without LOCs

The Null Hypothesis (i.e., There are no significant differences in the perceived security of tenure between customary landholders with land ownership certificates and customary landholders without land ownership certificates) was tested using Fisher's Exact Test at a 5\% significance level for each of the proxies established for the security of land tenure. The results are presented in Appendix B and, clearly show that the Null Hypothesis should be accepted on all counts/proxies (with the exception of one) suggesting that there is no significant difference in the perceptions held in the two strata over security of land.

On one count, however, that of protection from losing land rights, the Fisher's Exact test suggests that the perceptions of the customary landholders with LOC are statistically different from those of the others. Evidently, customary landholders with LOCs better perceive the strength of their land rights.

\section{Conclusion and Recommendation(s)}

This research shows that the traditional land administration system of Western Province is well organised and decentralised. It has a clearly defined process with responsible officials accountable at each level. The Barotse Royal Establishment (BRE) issues land ownership certificates (LOCs) that are locally binding but lack legal legitimacy. Nevertheless, all customary landholders perceive their land tenure under the customary land administration as secured. Hence, it can be inferred that the traditional land administration practices in Western Province collectively provide a de facto security of tenure.

It is shown in this research that the provision of land ownership certificates (LOCs) provides the customary landholders with a perceived protection from losing land rights. However, it does not entirely improve other perceptions of customary landholders towards tenure security. The LOCs are insignificant in enhancing the customary landholders' perceived security of tenure. The only plausible reason could be the absence of a legal recognition for these certificates within the Country.

The research makes the following recommendations. In order to address tenure insecurity on customary land, land ownership certificates should be encouraged and recognized as legal evidence of land ownership. De jure security of tenure will strengthen all perceptions held by customary landholders in Western Province. Specific provisions for customary land rights should be made in the land policy. Additionally, a statutory instrument should be issued under the provisions the Lands Act No. 5 of 1995 of the Laws of Zambia recognizing the customary land rights of landholders in possession of LOCs. An effective institutional framework should also be put in place. The experiences of Botswana and Tanzania provide an invaluable resource in this regard where the Land Boards and Villages are respectively granted legal recognition in the land administration process.

\section{Acknowledgement(s) and Dedication}

The authors acknowledge with gratitude the assistance provided by: the Provincial Lands Office in Western Province; the Provincial Agriculture Office; the Mongu Municipality; the BRE; Induna Inete; and Customary landholders in completing this research study.

This paper is dedicated to the profound memory of our dear friend and colleague: Dr. Austine Ng'ombe (Deceased) who has made an indelible mark in the understanding of Zambian land administration system. MHSRIP

\section{Reference}

Adams, M. (2004). Land reform, agriculture and poverty reduction. Working paper for the renewable natural resources and agriculture team, DFID policy discussion.

Adams, M. (2003). Land tenure policy and practice in Zambia: Issues relating to the development of the agricultural sector. DFID Consultancy Contract No. DCP/ZAM/018/2002, Mokoro Ltd. Oxford, UK.

Akrofi, E., \& Whittal, J. (2011). Traditional governance and customary peri-urban land delivery: a case study of Asokore-Mampong in Ghana. Capetown: University of Capetown.

Bornegrim, L., \& Collin, L. (2010). Administration of tribal land in Botswana (Unpublished bachelor thesis). University of Gavle. 
Brasselle et al. (2002). Land tenure security and investment incentives: puzzling evidence from Burkina Faso. Journal of Development Economics, 62(2), 373-418. http://dx.doi.org/10.1016/S0304-3878(01)00190-0

Broegaard, R. B. (2013). Biting the barefoot: Land titles and tenure security in the context of inequality. DISS Report 2013:32. Copenhagen.

Chileshe, R. (2005). Land tenure and rural livelihood in Zambia: Case studies of Kamena and St Joseph (Unpublished doctoral dissertation). University of Western Cape.

Deininger et al. (2006). Legal knowledge and economic development: the case of land rights in Uganda. World Bank Policy Research Working Paper 3868.

Deininger et al. (2009). Impacts of land certification on tenure security, investment and land markets: Evidence from Ethiopia. Environment for development. Discussion paper series.

Deininger, K. (2003). Land policies for growth and poverty reduction. Washington DC: World Bank.

Deininger, K., \& Feder, G. (2009). Land registration, governance and development: Evidence and implications for policy. The world-bank research observer, 24(2), 233-266. http://dx.doi.org/10.1093/wbro/lkp007

DFID. (2007). Land: Better access and secure land rights for poor people. London: Crown copyright.

Doebele, W. (1978). Selected issues in urban land tenure, urban land polices: issues and opportunities 1. Washington DC: World Bank.

Feder, G. (1987). Land registration and titling from an economists perspective: A case study in Rural Thailand. Survey review, 163-174.

GRZ. (1967). Report of the land commission. Lusaka: Republic of Zambia.

Holden-Stein, R. K. (2006). Land reform: The role of land markets and women's land rights in Malawi. Report No.36.

Hollingsworth, C. (2014). A framework for assessing security of tenure in post conflict context (Unpublished master's thesis), University of Twenty.

Kalabamu, T. (2000). Land tenure and management reforms in east and southern Africa- the case of Botswana. Land Use Policy, 17(4), 30th October, 305-319.

Kiddle, G. T. (2011). Informal Settlers, Perceived Security of Tenure and Housing Consolidation: Case Studies from Urban Fiji (Unpublished doctoral dissertation). Victoria University of Wellington.

Lamba, A. (2005). Land tenure management systems in informal settlements: a case study of Nairobi. (Unpublished master's thesis). University of Nairobi.

Lanjouw, J., \& Levy, P. (2002). Untitled: A study of formal and informal property rights in urban Ecuador. The Economic Journal, 112(482), 986-1019. http://dx.doi.org/10.1111/1468-0297.00067

Metcalfe, S., \& Kepe, T. (2008). Dealing land in the midst of poverty: Commercial access to communal land in Zambia. African and Asian Studies, 7, 253-257.

Mitchell, D. (2011). Assessing and responding to land tenure issues in disaster risk management. FAO land tenure manuals. Rome: FAO.

M'membe, F. (2005). The Zambia land tenure system and the process of land alienation: the need for land reform in Zambia (Unpublished Bachelor's thesis), University of Zambia. Lusaka.

Mulenga, S. (2014). Implications of the Lands Act of 1995 on the administration of customary land in Zambia: Recognition and conversion (Unpublished Bachelor's thesis), The Copperbelt University, Zambia.

Mulolwa, A. (2006). Customary rights in Zambia. Demystifying customary tenure in Zambia. Promoting land administration and good governance. 5th FIG Regional Conference. Accra, Ghana, March 8-11 2006. Accra.

Ng'ombe, A, \& Mushinge, A. (2014). The role of culture and beliefs in shaping customary land reform. International Journal of Social Science Research, 2(4).

Nsemiwe, N. (2007). Enhancing pro-poor land administration: vision for economic growth and development in Zambia. Land administration for economic growth. Strategic integration of surveying services. FIG Working Week 2007, Hong Kong SAR, China 13-17 May 2007. Hong Kong: FIG.

Payne, G. (2001). Urban land tenure policy options: Titles or rights? Habitat international, 25(3), 415-429 http://dx.doi.org/10.1016/S0197-3975(01)00014-5

Payne, G., \& Durand-Lasserve, A. (2012). Holding on: Security of tenure- types, policies, practices and challenges. Paper prepared for an expert group meeting on security of tenure convened by the special rapporteur on 22-23 October, 2012.

Payne, G., \& Quan, J. (2008). Secure land rights for all. UN-Habitat.

Quan et al. (2004). Land in Africa: Market asset or secure livelihood. Proceedings and summary of conclusions from the land in Africa. Conference held in London November 8-9, 2004. London: Russell press.

Republic of Botswana. (2010). 5, Chapter 32:02 Tribal Land. Retrieved July 15, 2014, from http://www.laws.gov.bw

Roth et al. (1995). Land tenure, land markets, and institutional transformation in Zambia. Land tenure center research paper 124 . 
Rugadya, M. A. (1999). Land Reform: the Ugandan Experience. Land use and Villagisation Workshop. Kigali, 20-21 September 1999.

Saunders, M., Lewis, P., \& Thornhill, A. (2009). Research Methods for Business Students. Prentice Hall, England

Sichone, F. (2008). Land administration in Zambia with particular reference to customary land. Paper presented at the seminar organized by Zambia Land Alliance, University of Zambia Chamber 28th June 2008. Lusaka.

Sichone, F. (2010). The system of land alienation in Zambia. A critical analysis of the legal and institutional framework (Unpublished master's thesis), University of Zambia. Lusaka.

Smith, R. (2004). Land tenure, fixed investments, and farm productivity: Evidence from Zambian Southern Province. World Development, 32(10). http://dx.doi.org/10.1016/j.worlddev.2004.05.006

Sundet, G. (2005). The 1999 Lands Act and Village Act: The technical analysis of the practical implications of the practical implications of the Acts. 28th February 2005- working draft.

UN-Habitat. (2008). Secure land rights for all. UN-Habitat.

UN-Habitat. (2011). Monitoring security of tenure in cities: People, land and policies. Nairobi: UN-Habitat.

UN-Habitat. (2014). Land tenure security in selected countries. Synthesis report No.2.

Usamah et al. (2012). Perceptions of tenure security in Camalig municipality in the Philippines. Fig working week: Knowing to manage the territory, protect the environment, and evaluate the cultural heritage. Rome, Italy 6-10 May 2012. Rome: Fig.

Van-Asperen, P., \& Mulolwa, A. (2008). Customary land in Zambia. Improvement of customary tenure security as pro-poor tool for land development- A Zambia case study. Promoting land administration and good governance. 5th FIG Regional Conference, Accra, Ghana, March 8-11 2008. Accra: FIG.

Van-Gelder, J. (2007). Feeling and thinking: Quantifying the relationship between perceived tenure security and housing improvement in an informal neighborhood in Buenos Aires. Habitat International, 31, 219-231 http://dx.doi.org/10.1016/j.habitatint.2007.02.002

Van-Loenen, B. (1999). Land tenure in Zambia. University of Maine.

White, R. (2009). Tribal land administration in Botswana. Policy Brief 31.

Willy, A. (2003). Governance and land relations: A review of decentralization of land administration and management in Africa. IIED. 
Appendix A

Sample land ownership certificate (LOC)

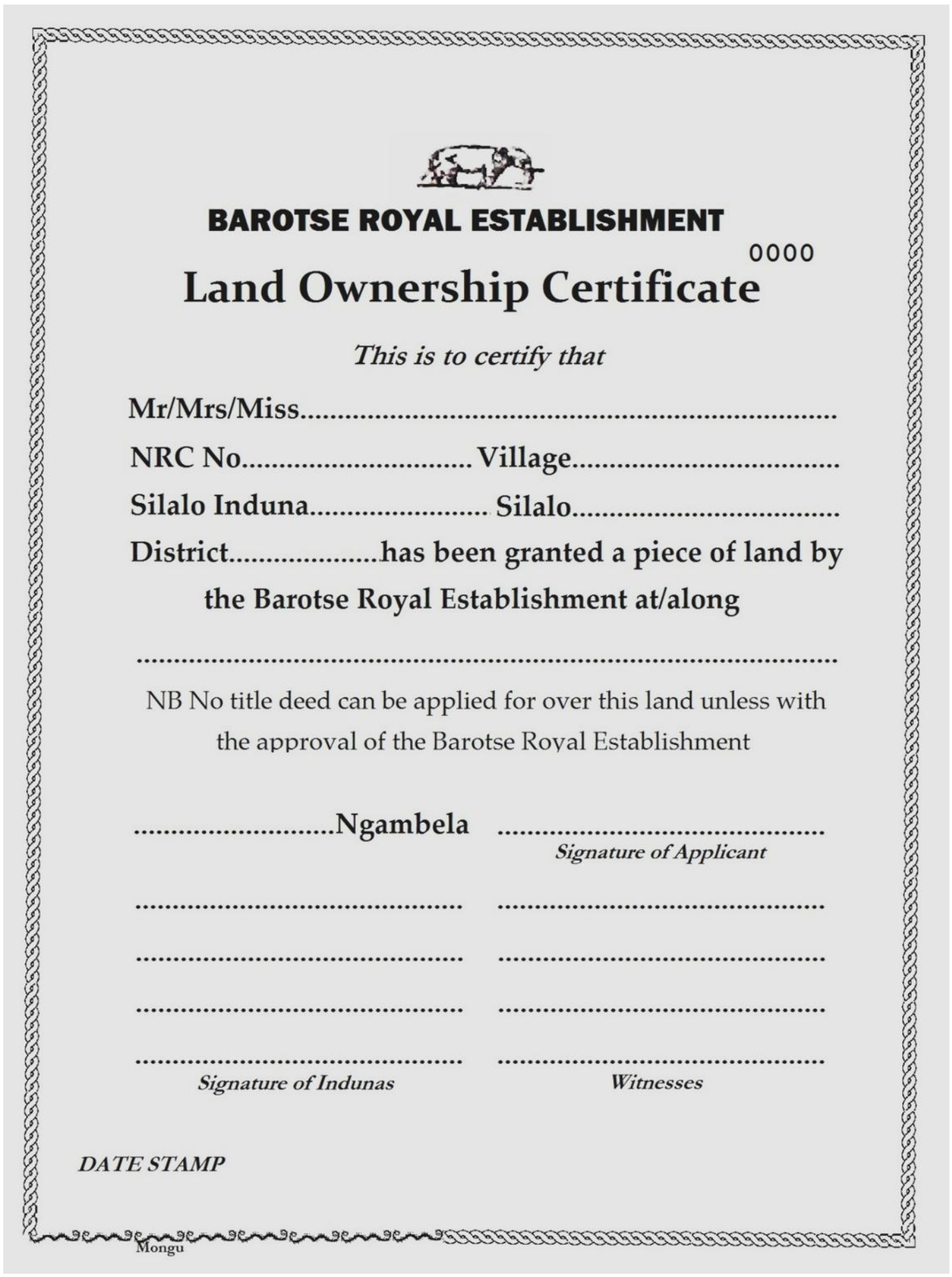

Description: A replica of the Land Ownership Certificate (LOC) - Western Province Source: Adapted from BRE Records 


\section{Appendix B}

Table 4. Fishers' Exact Test on Data from Customary Landholders in Mongu (Zambia)

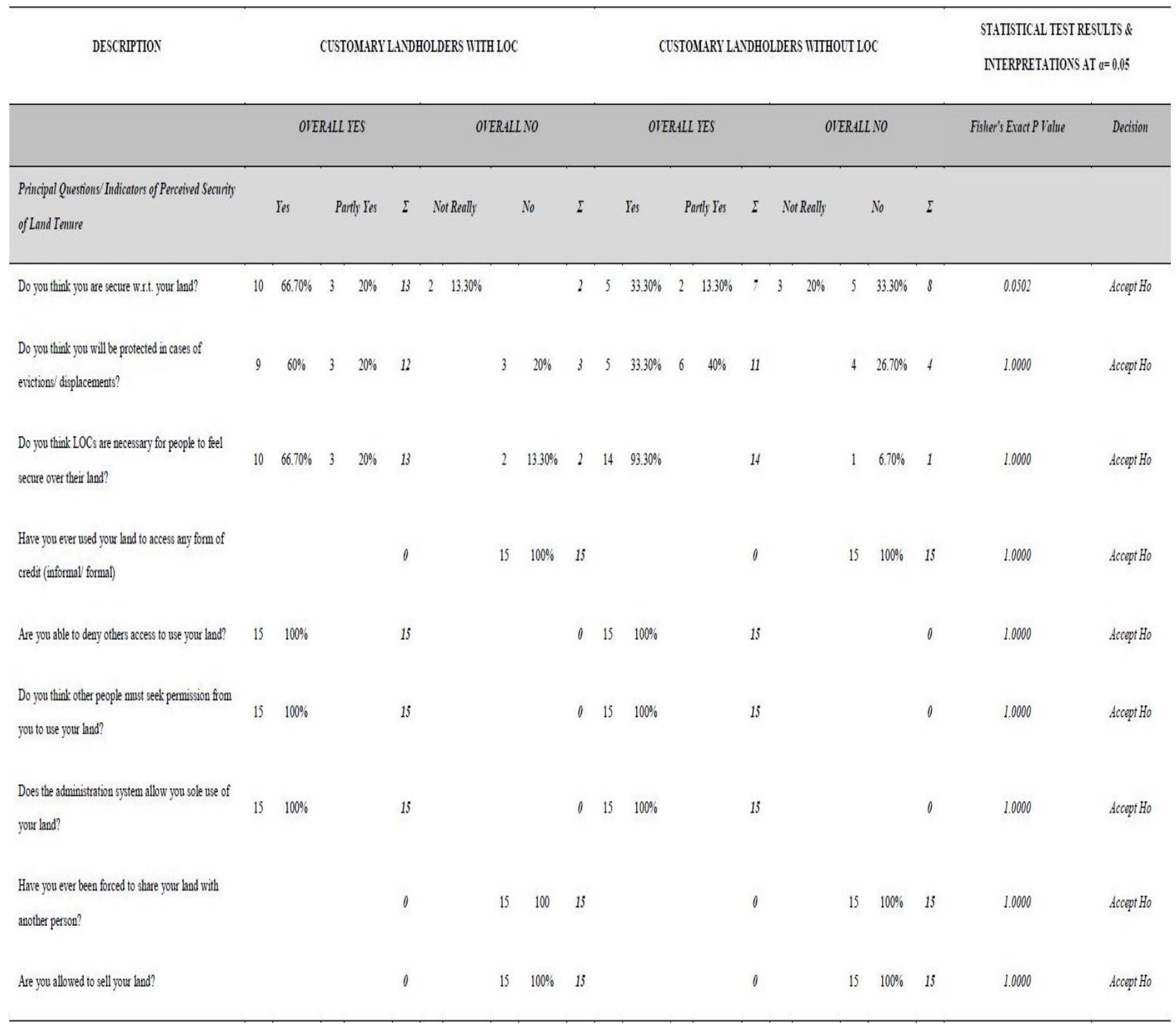


Table Continued From Previous Page

\begin{tabular}{|c|c|c|c|c|c|c|c|c|c|c|c|c|c|c|c|c|c|c|c|c|c|}
\hline \multirow[t]{2}{*}{ DESCRIPTION } & \multicolumn{9}{|c|}{ CUSTOMARY LANDHOLDERS WITH LOC } & \multicolumn{9}{|c|}{ CUSTOMARY LANDHOLDERS WTTHOUT LOC } & \multicolumn{3}{|c|}{$\begin{array}{l}\text { STATISTICAL TEST RESULTS \& } \\
\text { INTERPRETATIONS AT } a=0.05\end{array}$} \\
\hline & \multicolumn{4}{|c|}{ OVERALL IES } & \multicolumn{5}{|c|}{ OVERALL NO } & \multicolumn{5}{|c|}{ OVERALL IES } & \multicolumn{4}{|c|}{ OIERALLNO } & & \multirow[t]{2}{*}{ Fisher's Exact PValue } & \multirow[t]{2}{*}{ Decision } \\
\hline $\begin{array}{l}\text { Principal Questions/Indicators of Perceived Security } \\
\text { of Land Tenure }\end{array}$ & & Yes & & artly Yes & $\Sigma$ & & it Really & & No & $\Sigma$ & & Yes & & artly Yes & $\Sigma$ & Not Really & & No & $\Sigma$ & & \\
\hline Do you think you are protected from losing your land? & 10 & $66.70 \%$ & 4 & $26.70 \%$ & 14 & & & 1 & $6.70 \%$ & 1 & 2 & $13.30 \%$ & 6 & $40 \%$ & 8 & & 7 & $46.70 \%$ & 7 & 0.0352 & Reject Ho \\
\hline $\begin{array}{l}\text { Do you think you are protected against evictions' } \\
\text { displacements? }\end{array}$ & 13 & $86.70 \%$ & 2 & $13.30 \%$ & 15 & & & & & 0 & 7 & $46.70 \%$ & 5 & $33.30 \%$ & 12 & & 3 & $20 \%$ & 3 & 0.2241 & Accept Ho \\
\hline Do you think customary landholders with $\mathrm{L} O \mathrm{C}$ s are & & & & & & & & & & & & & & & & & & & & & \\
\hline $\begin{array}{l}\text { more secure/ protected than customary landholders } \\
\text { without LOCs? }\end{array}$ & 11 & $73.30 \%$ & 3 & $20 \%$ & 14 & 1 & $6.70 \%$ & & & 1 & 13 & $86.70 \%$ & 2 & $13.30 \%$ & 15 & & & & 0 & 1.0000 & Accept Ho \\
\hline Are your land rights recognized by the community? & 15 & $100 \%$ & & & 15 & & & & & 0 & 9 & $60 \%$ & 6 & $40 \%$ & 15 & & & & 0 & 1.0000 & Accept Ho \\
\hline $\begin{array}{l}\text { Does the customary administration system protect you } \\
\text { from people who claim your land? }\end{array}$ & 10 & $66.70 \%$ & 2 & $13.30 \%$ & 12 & 3 & $20 \%$ & & & 3 & 8 & $53.30 \%$ & 5 & $33.30 \%$ & 13 & $13.30 \%$ & & & 2 & 1.0000 & Accept Ho \\
\hline $\begin{array}{l}\text { Are your land rights recognized by the customary land } \\
\text { administration system? }\end{array}$ & 15 & $100 \%$ & & & 15 & & & & & 0 & 15 & $100 \%$ & & & 15 & & & & 0 & 1.0000 & Accept Ho \\
\hline AVERAGE FREQUENCY & & & & & 11 & & & & & 4 & & & & & 10 & & & & 5 & 1.0000 & Accept $\mathrm{Ho}$ \\
\hline
\end{tabular}

Description: Dataset with results of the Fishers' Test; Categories included- Overall Yes for 'Partly Yes and Yes' and Overall No for 'Not Really and No' Source: Authors, Field Survev 2014

\section{$(\mathrm{ccc})$ EY}

This work is licensed under a Creative Commons Attribution 3.0 License. 